\title{
ATGALINIO ŽINGSNIAVIMO POVEIKIS KELIO SĄNARIO OSTEOARTROZEI
}

\author{
Vilma Gaučytė, Svetlana Lenickienė \\ Vilniaus universiteto ligoninès Santariškių kliniku Reabilitacijos, fizinès ir sporto medicinos \\ katedra, Vilniaus universiteto Medicinos fakulteto Reabilitacijos, fizinès ir sporto medicinos centras
}

Raktažodžiai: kelio sąnario osteoartrozè, kelio sąnario skausmas, atgalinis žingsniavimas, eisena.

\begin{abstract}
Santrauka
Šiuo tyrimu siekta ịverinti atgalinio žingsniavimo poveikị osteoartroze sergančių pacientų pažeisto kelio sąnario funkcijai. 30 pacientų, kuriems diagnozuota $\mathrm{II}^{\circ}$ - $\mathrm{IV}^{\circ}$ kelio sąnario osteoartrozè, atsitiktinès atrankos būdu suskirstyti ị tiriamają ir kontrolinę grupes vykdè 10 užsièmimų kineziterapijos pratimų programą, papildytą ịprastu ir atgaliniu žingsniavimu. Pacientų funkcinẻ būklẻ testuota prieš ir po kineziterapijos programų taikymo: ịvertintas skausmo pojūtis, šlaunies lenkèjų ir tiesejjų, kelio lenkèjų ir tiesèjų, čiurnos lenkèjų ir tiesèjų raumenų izometrinè jèga, apatinių galūnių funkcinè būklè. Duomenų analizè atlikta naudojant statistinès analizès „SPSS Windows 20.0“ ir Excel 2010 programas. Nustatyta, kad atgaliniu ir įprastu žingsniavimu papildytos kineziterapijos programos statistiškai patikimai gerina funkcinę būklę, mažina skausmo pojūtị kelio sąnario lenkimo metu, didina šlaunies lenkejjų, šlaunies tiesèjų, kelio lenkèjų, kelio tiesėjų, čiurnos lenkejjų ir čiurnos tiesèjų raumenų grupių izometrinę jègą. Atgalinio žingsniavimo metodas mažina skausmo pojūtį kelio sąnario tiesimo metu, reikšmingiau nei iprastas ejjimas didina šlaunies tiesèjų ir čiurnos lenkejjų raumenų izometrinę jègą.
\end{abstract}

\section{Ivadas}

Senyvas amžius, moteriška lytis, genetinis polinkis, sąnarị supančių raumenų grupių jègų disbalansas, sąnariui tenkančios mechaninès apkrovos kiekis yra pagrindiniai rizikos veiksniai, provokuojantys patologinius sąnario kremzlès ir pokremzlinio kaulo sandaros procesus [1]. Kelio sąnario osteoartrozè yra degeneracinè liga, kai pirminiai biocheminiai ir morfologiniai pakitimai lemia antrinius uždegimo proceso ir sąnario funkcijos pokyčius: skausmą, ribotą sąnario judesių amplitudę, struktūrų deformaciją, sąnario stabilumą užtikrinančių raumenų silpnumą [2]. Vidurio ir vakarų Europos šalyse 7-18 proc. vyresnio amžiaus žmonių stebima simptominė kelio sąnario osteoartrozė [3, 4], ịtariama pasireiškiant rytiniam sąstingiui, krepitacijai, sinovito lydimam sąnario pabrinkimui ir skausmui judesių metu, dažniausiaijuntamam vidinèje kelio sąnario dalyje [5].

Sergantiems kelio osteoartroze, genus varus deformacija yra būdinga sąnario padètis [6, 7]. Šis struktūrinis defektas yra svarbus faktorius, lemiantis šoninị sąnario laisvumą, kompensuojamą didesniu išorinių mechaninių jègų poveikiu vidinei kelio sąnario sričiai $[8,9]$. Nuolatinis aktyvių ir pasyvių minkštụjų audinių dirginimas [9] lemia tęstinę pirminių patologinių procesų eigą, dinaminių judesių metu provokuojamą vidinès kelio sąnario dalies skausmą $[10,11]$.

Skausmas sutrikdo funkcinius judesius: apsunkina svorio pernešimo veiksmus vaikštant, lipant laiptais, atliekant daiktų kèlimo, perkèlimo judesius [3].Teigiama, kad vengdami skausmo, pacientai ịgyja būdingus eisenos pokyčius: žingsnį pradèdami ir baigdami pilna pèda, ejjimo ciklo metu riboja čiurnos ir kelio sąnarių judesius, nesąmoningai vengia apkrauti pažeistą galūnę pasirinkdami itin trumpą padèties žingsnio atramos fazèje trukmę $[12,13]$. Klaidingas eisenos stereotipas sutrikdo neuroraumeninę koordinaciją apatinèse galūnėse: vystosi kelio sąnario sustingimas, provokuojantis stipresnę kelio sąnarị veikiančią mechaninę jègą galūnès kontakto su paviršiumi metu $[13,14]$.

Tyrimo tikslas: ịvertinti atgalinio žingsniavimo poveikị osteoartroze sergančių pacientų pažeisto kelio sąnario funkcijai.

\section{Tyrimo kontingentas ir metodika}

Nuo $2015 \mathrm{~m}$. rugsejo mènesio iki $2016 \mathrm{~m}$. balandžio mènesio VUL Santariškių klinikų Reabilitacijos, fizinès ir sporto medicinos centre, Ambulatorinès reabilitacijos skyriuje vykdytame tyrime dalyvavo 30 pacientų (amžiaus vidurkis $-61,1 \pm 10,75$ metai), kuriems diagnozuota $\mathrm{II}^{\circ}-\mathrm{IV}^{\circ}$ 
kelio sąnario osteoartrozè. I tyrimą neịtraukti pacientai su kliniškai patvirtintais patologiniais pakitimais kituose apatinių galūnių sąnariuose; pacientai su instrumentiniais tyrimais patvirtintais, neurolo-

1 lentelè. Bendrosios pacientų charakteristikos

$p^{*}$ - statistinio reikšmingumo skirtumas tarp nepriklausomu imčiu kintamuju (Chi square testas); $p^{* *}$ - statistinio reikšmingumo skirtumas tarp nepriklausomu imčiu kintamuju (Stjudento kriterijus).

\begin{tabular}{|c|c|c|c|c|c|c|}
\hline \multirow{2}{*}{\multicolumn{3}{|c|}{ Rodikliai }} & \multirow{4}{*}{$\begin{array}{c}\begin{array}{c}\text { Visi pacientai } \\
(\mathrm{n}=30)\end{array} \\
25(83,3 \%) \\
5(16,7 \%)\end{array}$} & \multirow{2}{*}{\multicolumn{2}{|c|}{ Grupé }} & \multirow{4}{*}{$\begin{array}{c}\frac{\mathrm{p}}{\mathrm{p}} \\
\text { reikšmé }\end{array}$} \\
\hline & & & & & & \\
\hline & & & & \multirow{2}{*}{$\begin{array}{c}\begin{array}{c}\text { Kontroliné } \\
(\mathrm{n}=15)\end{array} \\
13(86,7 \%)\end{array}$} & $\begin{array}{c}\begin{array}{c}\text { Tiriamoji } \\
(\mathrm{n}=15)\end{array} \\
12(80.0 \%)\end{array}$ & \\
\hline & \begin{tabular}{|l|l|} 
Myras \\
Vyras
\end{tabular} & $\mathrm{n}(\%)$ & & & & \\
\hline \multicolumn{2}{|c|}{ Amžius (metai) } & $\mathrm{M}+\mathrm{SN}$ & $61,1 \pm 10,75$ & $64,7 \pm 9,54$ & $57,4 \pm 10,93$ & $0,060 * *$ \\
\hline \multicolumn{2}{|c|}{ Ūgis (m) } & $\mathrm{M}+\mathrm{SN}$ & $1,65 \pm, 10$ & $1,65 \pm, 11$ & $1,64 \pm, 09$ & $0,732 * *$ \\
\hline \multicolumn{2}{|c|}{ Svoris (kg) } & $\mathrm{M}+\mathrm{SN}$ & $90,0 \pm 18,1$ & $90,5 \pm 17,6$ & $89,6 \pm 19,3$ & $0,885^{* *}$ \\
\hline \multicolumn{2}{|c|}{$\mathrm{KMI}\left(\mathrm{kg} / \mathrm{m}^{2}\right)$} & $\mathrm{M}+\mathrm{SN}$ & $33,30 \pm 6,6$ & $33,04 \pm 4,90$ & $33,56 \pm 8,13$ & $0,834 * *$ \\
\hline
\end{tabular}

2 lentelè. Kelio sąnario funkcijos rodikliai prieš kineziterapijos taikymą

\begin{tabular}{|c|c|c|c|c|}
\hline \multicolumn{2}{|c|}{ Rodikliai } & \multirow{2}{*}{$\begin{array}{c}\begin{array}{c}\text { Kontrolinè } \\
(\mathrm{n}=15) \\
\mathrm{M} \pm \mathrm{SD}\end{array} \\
3,9 \pm 2,40\end{array}$} & \multirow{2}{*}{$\begin{array}{c}\begin{array}{c}\text { Tiriamoji } \\
(\mathrm{n}=15)\end{array} \\
\mathrm{M} \pm \mathrm{SD} \\
4,2 \pm 2,36\end{array}$} & \multirow{2}{*}{$\begin{array}{c}\text { p reikšmè } \\
0,755\end{array}$} \\
\hline Kelio skausmo pojūtis & lenkime & & & \\
\hline (balai) & tiesime & $2,8 \pm 1,79$ & $4,3 \pm 2,28$ & 0,640 \\
\hline \multicolumn{2}{|c|}{ Šlaunies lenkèjų raumenų jèga (N) } & $96,0 \pm 29,98$ & $105,6 \pm 32,50$ & 0,411 \\
\hline \multicolumn{2}{|c|}{ Šlaunies tiesèjų raumenų jèga $(\mathrm{N})$} & $74,0 \pm 27,21$ & $71,3 \pm 26,29$ & 0,781 \\
\hline \multicolumn{2}{|c|}{ Kelio lenkèjų raumenų jèga $(\mathrm{N})$} & $66,4 \pm 19,94$ & $68,3 \pm 32,94$ & 0,855 \\
\hline \multicolumn{2}{|c|}{ Kelio tiesėjų raumenų jèga $(\mathrm{N})$} & $77,0 \pm 32,54$ & $71,4 \pm 32,33$ & 0,644 \\
\hline \multicolumn{2}{|c|}{ Čiurnos lenkèjų raumenų jèga (N) } & $50,2 \pm 17,92$ & $45,6 \pm 17,73$ & 0,483 \\
\hline \multicolumn{2}{|c|}{ Čiurnos tiesėjų raumenų jèga (N) } & $58,9 \pm 20,31$ & $57,2 \pm 21,58$ & 0,820 \\
\hline
\end{tabular}

3 lentelè. Kelio sąnario funkcijos rodiklai po kineziterapijos taikymo

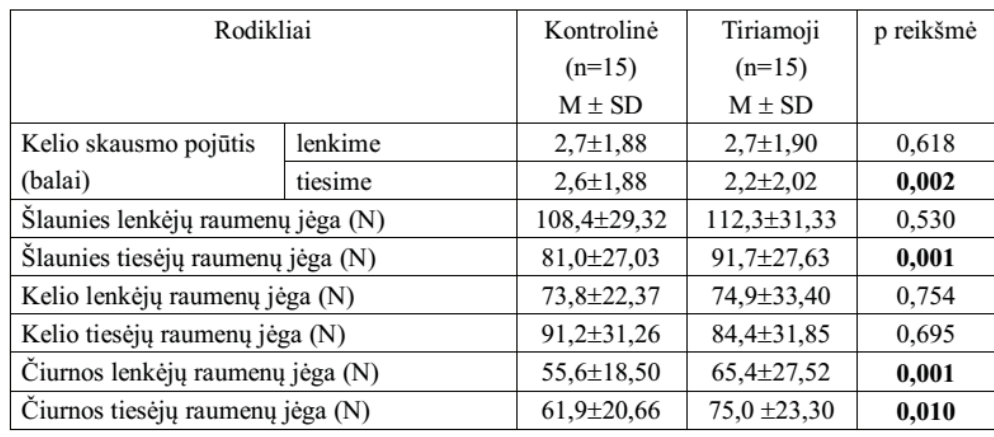

4 lentelè. Laiptinis mėginys prieš ir po kineziterapijos programų taikymo

\begin{tabular}{|c|c|c|c|c|c|c|c|c|}
\hline \multirow[t]{2}{*}{ Rodiklis } & \multicolumn{4}{|c|}{$\begin{array}{c}\text { Tiriamoji grupé }(\mathrm{n}=15) \\
\mathrm{M}+\mathrm{SN}\end{array}$} & \multicolumn{4}{|c|}{$\begin{array}{l}\text { Kontrolinè grupé }(\mathrm{n}=15) \\
\mathrm{M}+\mathrm{SN}\end{array}$} \\
\hline & I tyrimas & II tyrimas & pokytis & $\mathrm{p}^{*}$ & I tyrimas & II tyrimas & pokytis & $\mathrm{p}^{*}$ \\
\hline 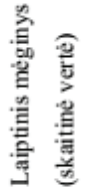 & $\begin{array}{c}29,2 \\
\pm 10,43\end{array}$ & $\begin{array}{c}35,3 \\
\pm 10,84\end{array}$ & $\begin{array}{c}6,1 \\
\pm 4,19\end{array}$ & ,000 & $\begin{array}{r}28,0 \\
\pm 9,29\end{array}$ & $\begin{array}{c}33,4 \\
\pm 9,49\end{array}$ & $\begin{array}{c}5,4 \\
\pm 3,32\end{array}$ & , 000 \\
\hline $\mathrm{p}^{* *}$ & & & & & & & & ,479 \\
\hline
\end{tabular}

gine simptomatika pasireiškiančiais stuburo patologiniais pakitimais; pacientai, kuriems dèl patvirtintų širdies-kraujagyslių sistemos patologiju yra nustatytas tausojantis fizinio aktyvumo režimas.

Atsitiktinès atrankos būdu asmenys suskirstyti ị tiriamają ir kontrolinę grupes. Pagal Pasaulio sveikatos organizacijos (PSO) rekomendacijas, naudojant medicininiams tyrimams tinkamus prietaisus matuotas tiriamujų ūgis ir svoris, apskaičiuotas KMI. Pradinių tyrimo rodiklių nustatymas leidžia kontrolinę ir tiriamają grupes laikyti homogeniškomis (1 lentelè).

Klinikiniais rodikliais, leidžiančiais vertinti paciento būklę reabilitacijos proceso eigoje, pasirinktos: skaitmeninè analoginè skalè (vertinant skausmo intensyvumą, pasireiškianti aktyvių maksimalios amplitudès kelio lenkimo ir tiesimo judesių metu), šlaunies lenkèjų, šlaunies tiesèjų, kelio lenkèjų, kelio tiesėjų, čiurnos lenkèjų ir čiurnos tiesėjų raumenų izometrinès jègos matavimas (rankiniu dinamometru „Lafayette 01165), laiptinis mèginys, skirtas nustatyti apatinių galūnių funkcinei būklei. Panaudojant šiuos rodiklius pacientų funkcinè būklè testuota prieš (2 lentelè) ir po (3 lentelè) kineziterapijos programų taikymo.

Šlaunies lenkejjų ir tiesejjų izometrinè raumenų jëga vertinta remiantis K. Thorborg aprašyta metodika [15], kelio lenkejjų ir tiesëjų A.W. Andrews pateikta metodika [16], čiurnos lenkèjų ir tiesèjų raumenų jèga - R. A. Marmon tyrime pateikta vertinimo metodika [17].

Apatinių galūnių funkcinei būklei vertinti skirtas laiptinis mėginys vykdytas remiantis $\mathrm{A}$. Juocevičiaus, H. Guodžio pateiktomis metodinėmis rekomendacijomis [18]. Pacientų funkcinè būklè tyrimo metu testuota prieš ir po kineziterapijos programų taikymo (4 lentelè).

Tyrimo metu dalyviai vykdè 10 užsiẻmimu kineziterapijos programą. Kontrolinès grupès pacientams kineziterapijos pratimu programa buvo papildyta 10 minučių ịprastu èjimu èjimo takeliu, tiriamosios grupès pacientams $-10 \mathrm{mi}-$ nučių atgaliniu žingsniavimu ejjimo takeliu. Pirmas penkias programos taikymo dienas žingsniavimo ejjimo takeliu greitis abejose grupèse buvo didinamas nuo $0,8 \mathrm{~km} / \mathrm{h}$ iki $1,5 \mathrm{~km} / \mathrm{h}$. Nuo šeštosios iki dešimtosios programos taikymo dienos imtinai, naudotas toks pats $-1,5 \mathrm{~km} / \mathrm{h}$ 
ejjimo greitis, palaipsniui nuo $0^{\circ}$ iki $10^{\circ}$ (kas dieną pridedant $2^{\circ}$ ) didinant ejjimo takelio pakilimo kampą. Ėjimas èjimo takeliu kineziterapijos užsièmimo metu buvo pirma pacientų vykdomos programos dalis, naudota kartu su raumenų tempimo ir raumenu jejgos stiprinimo pratimais.

Statistinè tyrimo duomenų analizė atlikta naudojant statistinès analizès „Microsoft Excel 2010“ ir „SPSS Statistics 20.0" programas. Apskaičiuoti kintamujų rodiklių aritmetiniai vidurkiai ir jų standartiniai nuokrypiai. Kiekybinių tyrimo duomenu statistinis patikimumas vertintas pagal Stjudent ${ }^{\star} \mathrm{o}-\mathrm{t}$ kriterijų, $\mathrm{p}<0,05-$ skirtumą laikant statistiškai patikimu.

\section{Tyrimo rezultatai ir jų aptarimas}

Kelio sąnario skausmo pojūčio vertinimas. Po kineziterapijos taikymo, skausmo pojūtis lenkimo metu tiriamojoje grupeje statistiškai patikimai $\left(\mathrm{p}^{*}<0,05\right)$ sumažèjo vidutiniškai $1,5 \pm 1,44$ balo. Kontrolinèje grupejje skausmas lenkimo metu statistiškai patikimai $\left(\mathrm{p}^{*}<0,05\right)$ sumažèjo $1,2 \pm 1,38$ balo. Lyginant skausmo pokyčio lenkimo judesio metu vidurkius tarp grupių, statistiškai reikšmingo skirtu-

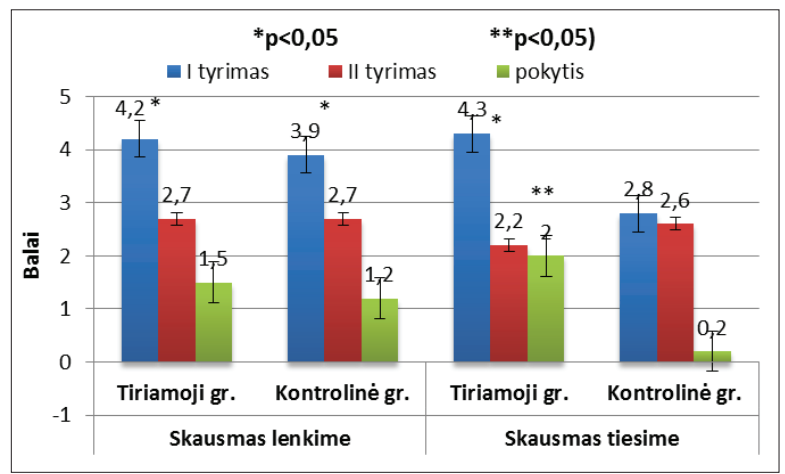

1 pav. Skausmo vertinimas

$p^{*}$ - statistinio reikšmingumo skirtumas tarp priklausomu imčiu kintamuju $p^{* *}$ - statistinio reikšmingumo skirtumas tarp nepriklausomu imčių kintamuju.

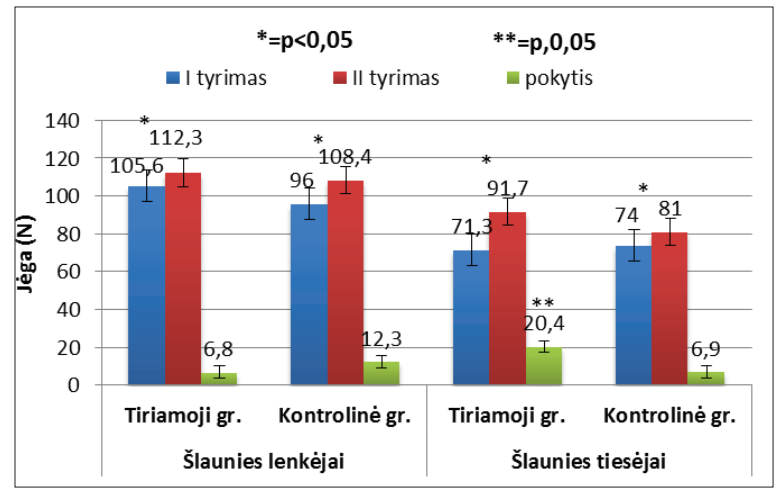

2 pav. Šlaunies lenkejjų ir tiesėjų raumenų izometrinè jèga mo nebuvo ( $\left.\mathrm{p}^{* *>0}, 05\right)$ (1 pav.).

Po kineziterapijos taikymo skausmo pojūtis atliekant tiesimo judesi tiriamojoje grupeje statistiškai patikimai $\left(\mathrm{p}^{*}<0,05\right)$ sumažejo vidutiniškai $2,0 \pm 1,55$ balo. Kontrolinèje grupeje skausmas tiesimo metu statistiškai nereikšmingai ( $\left.p^{*}>0,05\right)$ sumažejo vidutiniškai $0,2 \pm 1,51$ balo. Lyginant skausmo pokyčio tiesimo metu vidurkius tarp grupių nustatytas statistiškai reikšmingas skirtumas $\left(\mathrm{p}^{* *<0,05)}(1\right.$ pav.).

Apatinių galūnių izometrinès raumenų jègos vertinimas. Po kineziterapijos programos taikymo tiriamojoje grupeje šlaunies lenkejjų raumenų izometrinè jèga statistiškai patikimai $\left(\mathrm{p}^{*}<0,05\right)$ padidejo vidutiniškai $6,8 \mathrm{~N} \pm 8,09 \mathrm{~N}$. Kontrolinèje grupejje šlaunies lenkèjų izometrinè jèga statistiškai patikimai $\left(\mathrm{p}^{*}<0,05\right)$ padidèjo vidutiniškai $12,3 \mathrm{~N} \pm 7,05 \mathrm{~N}$. Lyginant šlaunies lenkèjų izometrinès jègos pokyčio vidurkius tarp tiriamosios ir kontrolinès grupių statistiškai reikšmingo skirtumo nerasta ( $\mathrm{p}^{* *>0,05)}(2$ pav.).

Šlaunies tiesèjų raumenų izometrine jèga po kineziterapijos taikymo tiriamojoje grupejje statistiškai patikimai

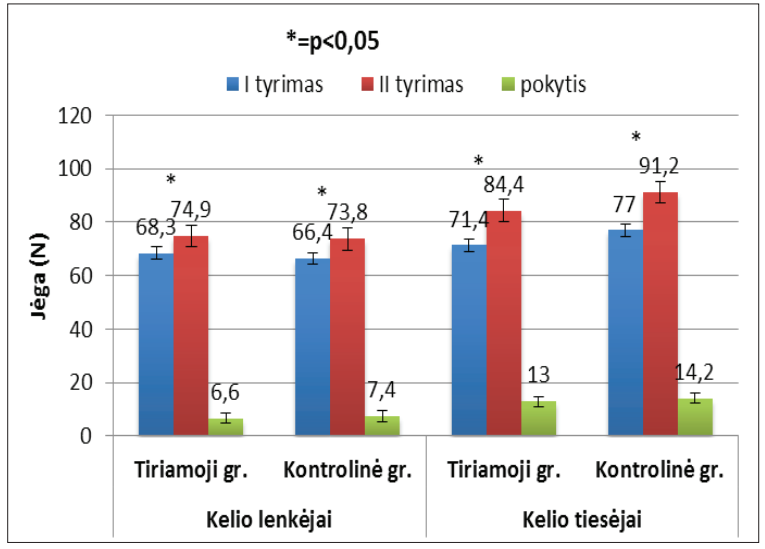

3 pav. Kelio lenkèjų ir tiesèjų izometrinè jèga

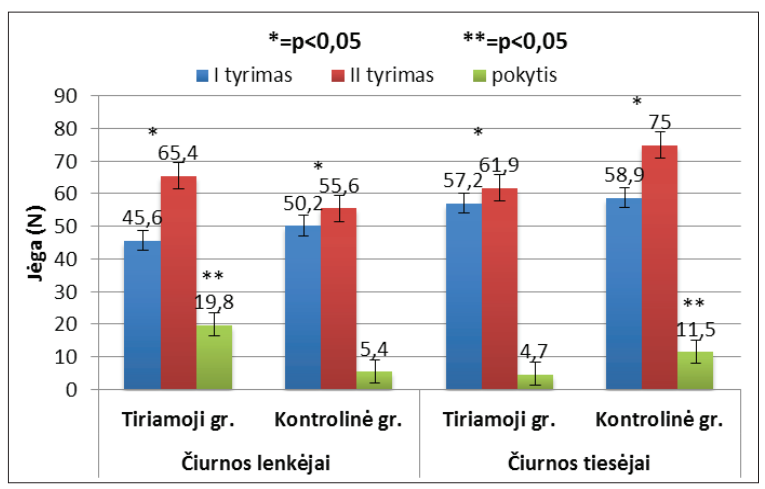

4 pav. Čiurnos lenkèjų ir tiesejjų raumenų izometrinè jèga 
$\left(p^{*}<0,05\right)$ padidejo vidutiniškai $20,4 \mathrm{~N} \pm 13,67 \mathrm{~N}$. Kontrolinèje grupèje šlaunies tiesẻjų izometrinè jèga statistiškai patikimai $\left(\mathrm{p}^{*}<0,05\right)$ padidejjo vidutiniškai $6,9 \mathrm{~N} \pm 4,52 \mathrm{~N}$. Lyginant šlaunies tiesejjų izometrinès jègos pokyčio vidurkius tarp tiriamosios ir kontrolinès grupių, nustatytas statistiškai reikšmingas skirtumas $\left(\mathrm{p}^{* *}<0,05\right)(2$ pav.).

Kelio lenkèjų raumenų izometrinè jèga po kineziterapijos programos taikymo tiriamojoje grupeje statistiškai patikimai $\left(\mathrm{p}^{*}<0,05\right)$ padidèjo vidutiniškai $6,6 \mathrm{~N} \pm 7,60 \mathrm{~N}$. Kontrolinèje grupejje kelio lenkejjų izometrinè jëga statistiškai patikimai $\left(\mathrm{p}^{*}<0,05\right)$ padidèjo vidutiniškai $7,4 \mathrm{~N} \pm 5,33 \mathrm{~N}$. Lyginant kelio lenkejjų izometrinès jègos pokyčio vidurkius tarp tiriamosios ir kontrolinès grupių, statistiškai reikšmingo skirtumo nerasta ( $\left.\mathrm{p}^{* *}>0,05\right)$ ( 3 pav.).

Po įvykdytos programos tiriamojoje grupeje kelio tiesèjų raumenų izometrinè jèga statistiškai patikimai $\left(\mathrm{p}^{*}<0,05\right)$ padidejo vidutiniškai $13,0 \mathrm{~N} \pm 7,42 \mathrm{~N}$. Kontrolinëje grupejje kelio tiesejjų izometrine jëga statistiškai patikimai $\left(\mathrm{p}^{*<0,05)}\right.$ padidèjo vidutiniškai $14,2 \mathrm{~N} \pm 7,99 \mathrm{~N}$. Lyginant kelio tiesèjų izometrinès jẻgos pokyčio vidurkius tarp tiriamosios ir kontrolinès grupių statistiškai reikšmingo skirtumo nerasta ( $\mathrm{p}^{* *>0,05)}$ (3 pav.).

Čiurnos lenkèjų raumenų izometrinès jèga po kineziterapijos programos taikymo tiriamojoje grupeje statistiškai patikimai $\left(\mathrm{p}^{*}<0,05\right)$ padidejo vidutiniškai $19,8 \mathrm{~N} \pm 14,71 \mathrm{~N}$. Kontrolinèje grupejje čiurnos lenkèjų raumenų jèga statistiškai patikimai $\left(\mathrm{p}^{*}<0,05\right)$ padidejjo vidutiniškai $5,4 \mathrm{~N} \pm 2,32 \mathrm{~N}$. Lyginant čiurnos lenkejjų raumenų jëgos pokyčio vidurkius tarp tiriamosios ir kontrolinès grupių pastebètas statistiškai reikšmingas skirtumas ( $\mathrm{p}^{* *<0,05)}(4 \mathrm{pav}$.).

Čiurnos tiesejų raumenų izometrinè jèga po kineziterapijos programos taikymo tiriamojoje grupejje statistiškai patikimai $\left(\mathrm{p}^{*}<0,05\right)$ padidèjo vidutiniškai $4,7 \mathrm{~N} \pm 5,68 \mathrm{~N}$. Kontrolinèje grupejje čiurnos tiesèjų raumenų jèga statistiškai patikimai $\left(\mathrm{p}^{*}<0,05\right)$ padidèjo vidutiniškai $11,5 \mathrm{~N} \pm 7,67 \mathrm{~N}$. Lyginant čiurnos tiesėjų raumenų izometrinès jègos pokyčio vidurkius tarp tiriamosios ir kontrolinès grupių, nustatytas statistiškai reikšmingas skirtumas $\left(\mathrm{p}^{* *}<0,05\right)$ ( 4 pav.).

Kineziterapijos programų poveikio funkcinei būklei vertinimas. Nustatyta, kad tyrimo metu pritaikius kineziterapijos programą, laiptinio mėginio rezultatai statistiškai patikimai pagerejo ir tiriamojoje, ir kontrolinèje grupejje $\left(\mathrm{p}^{*}<0,05\right)$. Tiriamojoje grupejje šis pokytis siekè vidutiniškai $6,1 \pm 4,19$, kontrolineje $-5,4 \pm 3,52$. Lyginant laiptinio mėginio skaitinès vertès pokyčio vidurkių rezultatus tarp grupių, statistiškai patikimas skirtumas nebuvo nustatytas $\left(\mathrm{p}^{* *}>0,05\right)$.

Teigiama, kad kelio sąnario osteartroze sergantiems pacientams yra naudinga taikyti pratimus ir veiklas, kuriuose lavinama svorio pernašos funkcija remiantis pažeisto sąna- rio galūne [19, 20]. Jansen K., Myngeyon L. teigimu, atgalinis žingsniavimas palyginti su ịprastu èjimu yra pranašesnis dèl mažesnès klubo ir kelio sąnariams tiesimo judesių metu tenkančios mechaninès apkrovos [19, 20]. Einant atgal, aktyvesni čiurnos sąnario judesiai pèdos lenkimo ir tiesimo metu amortizuoja žingsnius, tad jègos absorbcija kelio sąnaryje yra mažesnè. Tai lemia mažèjančius kelio sąnario skausmo intensyvumo, didejjančius supančiųų raumenu aktyvumo pokyčius $[12,13]$. Atlikto tyrimo metu atgalini žingsniavimą vykdžiusioje grupejje nustatyti reikšmingi apatiniu galūniu raumenu jègos pokyčiai lydimi sumažejusio skausmo kelio sąnario tiesimo metu. Remiantis gautais duomenimis stebime, kad atlikto tyrimo rezultatai patvirtina biomechaninemis studijomis $[12,13,19,20]$ nustatytus atgalinio žingsniavimo metu apatinèms galūnèms tenkančios mechaninès apkrovos pasiskirstymo poveikio ypatumus.

\section{Išvados}

1. Atgaliniu ir ịprastu žingsniavimu papildytos kineziterapijos programos statistiškai patikimai mažina skausmo pojūtị kelio sąnario lenkimo metu, didina šlaunies lenkejjų, šlaunies tiesèjų, kelio lenkèjų, kelio tiesèjų, čiurnos lenkèjų ir čiurnos tiesėjų raumenų grupių izometrinę jègą. Atgalinio žingsniavimo metodas mažina skausmo pojūtį kelio sąnario tiesimo metu, reikšmingiau nei ịprastas ejjimas didina šlaunies tiesèjų ir čiurnos lenkejjų raumenų izometrinę jègą.

2. Kineziterapijos programos, papildytos atgaliniu arba ịprastu žingsniavimu, reikšmingai pagerina sergančių kelio sąnario osteoartroze funkcinę būklę.

\section{Literatūra}

1. Funck-Brentano T, Richette P. What is new on the osteoarthritis front? European Musculoskeletal Review 2010;5(2):8-10.

2. Kawaguchi H. Endochondral ossification signals in cartilage degradation during osteoarthritis progression in experimental mouse models. Mol Cells 2008;25(1):1-6.

3. Nguyen US, Zhang Y, Zhu Y, Niu J, Zhan B. Increasing prevalence of knee pain and symptomatic knee osteoarthritis: survey and cohort data. Ann Intern Med 2011;155(11):725-32.

http://dx.doi.org/10.7326/0003-4819-155-11-20111206000004

4. Leyland KM, Hart DJ, Javaid MK, Judge A. et al. The natural history of radiographic knee osteoarthritis: a fourteen-year population-based cohort study. Arthritis Rheum 2012;64(7):2243-51. http://dx.doi.org/10.1002/art.34415

5. Nemanius E. Sąnarių degeneracija ir lètinis skausmas: tebeieškoma trūkstamos sąsajos. Skausmo medicina, 2009;1(25):15.

6. Cameron J, Tile M. Knee conditions and disability. knee conditions and disability discussion paper prepared for the workplace 
safety and insurance appeals tribunal. Toronto: Aug 2013.

7. Issın A, Şahin V, Koçkara N, Gürsu S.S, Kurtuldu A, Yıldırım T. Is proximal tibia the major problem in varus gonarthrosis? Evaluation of femur and ankle. Joint Diseases and Related Surgery 2012;23(3):128-133.

8. Adouni M, Shirazi-Adl A. Evaluation of knee joint muscle forces and tissue stresses-strains during gait in severe OA versus normal subjects. J Orthop Res 2014;32:69-78.

http://dx.doi.org/10.1002/jor.22472

9. Shelburne K.B, Michael R, Pandy M.G. Contributions of muscles, ligaments, and the ground-reaction force to tibiofemoral joint loading during normal gait. J Orthop Res 2006;24:198390.

http://dx.doi.org/10.1002/jor.20255

10. Tanaka R, Ozawa J, Kito N, Moriyama H. Effects of exercise therapy on walking ability in individuals with knee osteoarthritis: a systematic review and meta-analysis of randomised controlled trials. Clinical Rehabilitation 2016:30(1):36-52.

http://dx.doi.org/10.1177/0269215515570098

11. Erhart-Hledika CJ, Favreb J, Andriacchia TP. New insight in the relationship between regional patterns of knee cartilage thickness, osteoarthritis disease severity, and gait mechanics. Journal of Biomechanics 2015;14(48):3868-75. http://dx.doi.org/10.1016/j.jbiomech.2015.09.033

12. Soda N, Ueki T, Aoki T. Three-dimensional motion analysis of the ankle during backward walking. J Phys Ther Sci 2013;25:747-49.

http://dx.doi.org/10.1589/jpts.25.747

13. Mundermann A, Dyrby CO, Andriacchi TP. Secondary gait changes in patients with medial compartment knee osteoarthritis; increased load on ankle, knee, hip during walking. Arthritis Rheum 2005;52:2835-44.

http://dx.doi.org/10.1002/art.21262

14. Neogi T, Guermazi A, Roemer F, Nevitt MC, Scholz J, ArendtNielsen L. et. al. Association of joint inflammation with pain sensitization in knee osteoarthritis. Arthritis \& Rheumatology 2016;3(68):654-61.

http://dx.doi.org/10.1002/art.39488

15. Thorborg K, Petersen J, Magnusson SP, Holmich P. Clinical assessment of hip strength using a hand-held dynamometer. Scand J Med Sci Sports 2010;20:493-501.

http://dx.doi.org/10.1111/j.1600-0838.2009.00958.x

16. Andrews AW, Thoma MV, Bohannon RW. Normative values for isometric muscle force measurements obtained with hand-held dynamometers. Physical Therapy 1996;76(3):248-59.

17. Marmon RA, Pozzi F, Alnahdi JA, Zeni A. The validity of plantarflexor strength measures obtained trought hand-held measurements of force. The International Journal of Sports Physical Therapy 2016;8(6):820-7.

18. Juocevičius A. Guodys H. Reumatinèmis sąnarių ligomis sergančiųų fizinio pajėgumo ir reabilitacijos potencialo kompleksinis vertinimas. M. Šumausko spaustuvè: Vilnius, 1985.

19. Minhyeon L, Jungyoon K, Jongsang S, Youngho K. Kinematic and kinetic analysis during forward and backward walking. Gait \& Posture 2013;38(4):674-8.

http://dx.doi.org/10.1016/j.gaitpost.2013.02.014

20. Jansen K, de Groote F, Jonkers I. Similar muscles contribute to horizontal and vertical accelerations of centre of mass in forward and backward walking:implications of neural control. J Neurophysio, 2012;107(12):3385-96.

http://dx.doi.org/10.1152/jn.01156.2011

\section{EFFECTS OF BACKWARDS WALKING IN KNEE OSTEOARTHRITIS \\ V. Gaučytė, S. Lenickienè}

Key words: knee osteoarthritis, knee pain, backward walking, gait.

Summary

The aim of this study was to evaluate the impact of backward walking in patients with knee osteoarthritis. This research was organised involving 30 (aged 61,1 $\pm 10,75$ years) outpatients with diagnosed $\mathrm{II}^{\circ}-\mathrm{IV}^{\circ}$ degree of knee osteoarthritis. Patients were randomly selected and divided into two groups: experimental and control. Participants performed a program of physical therapy lasting 10 days. An additional 10 min forward walking on monitorized tredmill was added to conrol group, while experimental group had additional 10 min backward walking on the same device.

The patients' functional status was tested before and after application of physical therapy programs. It was measured: pain intensity sentation, isometric strength of hip flexors and extensors, knee flexors and extensors, ankle flexors and extensors, functional status of lower extremities.

Data analysis was performed using statistical analysis SPSS 20.0 for Windows and Excel 2010 programs. Data were analysed using Student's t test. Statistical signifiance was defied as $p<0,05$. Physical therapy program supplemented by backward ant forward walking models decrease siginificantly pain sensation in the knee joint during flexion. It also increase significantly isometric muscle force of hip flexor, hip extensor, knee flexor, knee extensor, ankle flexor and ankle. The backward walking reduce significantly pain sensation in the knee joint. Functional status of lower extremities increased in both groups

Correspondence to: Vilmey@gmail.com

Gauta 2016-06-09 